\title{
Revolutions in the head: Darwin, Malthus and Robert M. Young
}

\author{
James A. Secord* \\ Department of History and Philosophy of Science, University of Cambridge, Free School Lane, \\ Cambridge, CB2 3RH, UK. \\ *Corresponding author: James A. Secord, Email: jas1010@cam.ac.uk.
}

\begin{abstract}
The late 1960s witnessed a key conjunction between political activism and the history of science. Science, whether seen as a touchstone of rationality or of oppression, was fundamental to all sides in the era of the Vietnam War. This essay examines the historian Robert Maxwell Young's turn to Marxism and radical politics during this period, especially his widely cited account of the 'common context' of nineteenth-century biological and social theorizing, which demonstrated the centrality of Thomas Robert Malthus's writings on population for Charles Darwin's formulation of the theory of evolution by natural selection. From Young's perspective, this history was bound up with pressing contemporary issues: ideologies of class and race in neo-Darwinian evolutionary theory, the revival of Malthusian population control, and the role of science in military conflict. The aim was to provide a basis for political action - the 'head revolution' that would accompany radical social change. The radical force of Young's argument was blunted in subsequent decades by disciplinary developments within history of science, including the emergence of specialist Darwin studies, a focus on practice and the changing political associations of the history of ideas. Young's engaged standpoint, however, has remained influential even as historians moved from understanding science as ideology to science as work.
\end{abstract}

Anyone who thinks history and long arguments are mystifying can stop reading after two sentences from Jerry Rubin: 'the New Left sprang, a predestined pissed-off child, from Elvis' gyrating pelvis ... there can be no social revolution without a head revolution and no head revolution without a social revolution.'

Bob Young, 'The new nation?', Bath Festival of Blues \& Progressive Music (1970), p. 29.

What does historical writing have to do with political action? This essay highlights a moment when the history of science became part of the struggle for radical social transformation. In the late 1960s, intellectual history was the field on which battles about the meaning of science were fought. For many commentators, the values of post-Galilean science were the natural ally of enlightened liberalism. For radical socialists of the New Left,

This paper was first presented at the Remembering Bob Young workshop organized by Simon Schaffer at Darwin College in March 2020. I wish to thank the many people who answered queries, contributed reminiscences and commented on drafts of this paper, including John Brooke, Rebecca Fallas, Sandra Herbert, Jerry Kutcher, Chris Lawrence, Bernard Lightman, Patrick Parrinder, Evelleen Richards, Martin Rudwick, Roger Smith, Gillian Sutherland and Jon Topham. I am especially grateful to Anne Secord, the two referees for this journal, and members of the Longest Nineteenth Century Reading Group for helpful discussion.

(c) The Author(s), 2021. Published by Cambridge University Press on behalf of British Society for the History of Science. This is an Open Access article, distributed under the terms of the Creative Commons Attribution licence (http://creativecommons.org/ licenses/by/4.0/), which permits unrestricted re-use, distribution, and reproduction in any medium, provided the original work is properly cited. 
however, natural science either provided the justification for scientific socialism, or alternatively had an ambiguous legacy as the source of environmental disaster, racial prejudice and military domination. As Theodore Roszak wrote in The Making of a Counter Culture (1969), 'Reason, material Progress, the scientific world view have revealed themselves in numerous respects as simply a higher superstition, based on dubious but wellconcealed assumptions about man and nature.' Intellectual foundations really mattered. ${ }^{1}$

The early writings of Robert M. Young and their fate in subsequent decades offer a revealing window on the changing politics of history of science. Born in Texas in 1935, Young studied philosophy and religion at Yale, and did a PhD on history of psychology at Cambridge, where he taught history of science for a decade from 1964 before leaving for London to engage in radical politics, publishing and eventually psychoanalytic practice. Like Jerry Ravetz, Gary Werskey and others in the radical science movement, Young brought American perspectives to bear on long-standing British controversies about the role of science in society. ${ }^{2}$ His lifetime goal was to understand human nature in the broadest sense. ${ }^{3}$

My focus is on Young's essays on the nineteenth-century disputes over the place of humans in nature, and particularly his most audacious claim, that the central theory of modern biological science originated as an answer to questions about politics, religion and economics. His celebrated article, 'Malthus and the evolutionists: the common context of biological and social theory', argued that Charles Darwin formulated the theory of evolution by natural selection as part of wide-ranging discussions of human nature and natural theology - particularly the controversy about Thomas Robert Malthus's An Essay on the Principle of Population (6th edn 1826). ${ }^{4}$ For many, especially biologists, this was anathema. Young's article, presented in 1968 and published in Past and Present in the following year, has long been taught and cited throughout the English-speaking world, but in ways that fail to recognize its iconoclastic aims. Its history illustrates not only the political functions of academic writing at a moment of dramatic upheaval, but also the ways in which the politics of understanding past science has changed since.

\section{Storming the citadel}

From the distance of fifty years, we can see Young's concern with Darwin, Malthus and the Victorian debate about 'man's place in nature' as the product of a specific historical juncture. The critical context was the Vietnam war. Notably, Young was one of the signatories of 'Bombing of North Vietnam', a letter to The Times in May 1966 from twenty-one

\footnotetext{
${ }^{1}$ Theodore Roszak, The Making of a Counter Culture: Reflections on the Technocratic Society and Its Youthful Opposition, New York: Anchor Books, 1969, p. 164. For science and technology in the 1960s see Jon Agar, 'What happened in the sixties?', BJHS (2008) 41, pp. 567-600; Everett Mendelsohn, 'The politics of pessimism: science and technology circa 1968', in Y. Ezrahi, E. Mendelsohn and H. Segal (eds.), Technology, Pessimism and Postmodernism, Dordrecht: Reidel, 1994, pp. 151-73; and Jerome R. Ravetz, 'Orthodoxies, critiques and alternatives', in Robert Olby, G.N. Cantor, J.R.R. Christie and M.J.S. Hodge (eds.), The Companion to the History of Modern Science, London: Routledge, 1990, pp. 898-908.

${ }^{2}$ Simone Turchetti, 'Looking for the bad teachers: the radical science movement and its transnational history', in Elena Aronova and Simone Turchetti (eds.), Science Studies during the Cold War and Beyond, New York, Palgrave Macmillan, 2016, pp. 77-101, esp. 82-4. Young did not import radical politics from the States, but rather American traditions of pragmatic philosophy and history of ideas. Unless otherwise mentioned, biographical information is taken from Young's website, http://psychoanalysis-and-therapy.com/rmyoung/index.html, accessed 10 April 2020.

${ }^{3}$ See especially C.J. Lawrence, 'Robert M. Young's Mind, Brain and Adaptation revisited', in this issue; and the papers on Young in Free Associations (2020) 80, pp. 1-50, esp. Roger Smith, 'The quest for humane relations in the trajectory of an intellectual life', pp. 11-26. For early recollections see Bob Young, 'Growing up in Texas in the 1950s', Ideas and Production: A Journal in the History of Ideas (1989) 9-10, pp. 31-43.

${ }^{4}$ Robert M. Young, 'Malthus and the evolutionists: the common context of biological and social theory', Past and Present (May 1969) 43, pp. 109-45.
} 
Cambridge academics against the conflict, organized by the classicist Moses Finley. ${ }^{5}$ For many, the war - with its use of napalm, Agent Orange and other science-based weapons revealed the profound involvement of the sciences in what President Dwight D. Eisenhower had termed the 'military-industrial complex'. Science, shown by the war to be complicit in social injustice and imperial domination, could not claim to be neutral and value-free. From this perspective, enquiring into the political origins of natural selection not only posed an interesting historical question; it stormed the scientific citadel.

From this perspective, the kind of history of science that Young had been advocating since 1964 from his position as a lecturer at Cambridge could serve as a force for resistance and liberation. The extent of his radical conversion cannot be overestimated. Born into a once prosperous family in Highland Park, the wealthiest Dallas suburb, Young had served in the Reserve Officer Training Corps (ROTC), and until the age of twenty had shared his parent's Presbyterian religious views. He brought to the countercultural cause all the evangelical fervour of a Texan abroad. With motorcycle, big boots, strong libido and an abrasive unwillingness to conform, Young presented himself as an incorruptible maverick in a hidebound world of sherry and college dinners. From 1968 he retooled his approach to the problem of human nature through an increasingly uncompromising turn to Marxism and radical politics. The central concern always remained the difficult task of reconciling intellectual enquiry and social action. ${ }^{6}$

The tension between thought and action as political forms is clear in 'The new nation?', an essay written by Young for the programme of the Bath Festival of Blues and Progressive Music in June 1970. This was a major event held in the wake of Woodstock, with an audience estimated at 150,000 and featuring bands from the Byrds and Jefferson Airplane to Pink Floyd and Led Zeppelin; it later became the inspiration for the annual gathering at Glastonbury. Young had already discussed 'the pop scene' on BBC radio and so was emerging as a noted commentator on contemporary music and social transformation. The essay, retitled as 'Functions of rock', appeared again in December as the lead article in a special issue of the New Edinburgh Review on The Underground (Figure 1). For this version, Young added a new preface and conclusion, more sceptical in tone than the original.

What, Young asked, was the relation between the 'head revolution' represented by rock and progressive music, and real-life social and political revolution? What did it mean when the Jefferson Airplane's recently released 'Volunteers' advocated revolution in the streets, or when Bob Dylan sang 'You don't need a weatherman to know which way the wind blows'?

This raises the question I have been posing in different forms throughout this article. How much has the music really freed people from oppression and repression, and how much is it a subtle accommodation with them? Gospel and blues, country \& western, even folk and protest were consolations. They gave strength, they even helped to produce some changes in the real world, but they always led, in the end, away from total commitment to the kinds of integrated social and political and personal changes that people dream of when they invoke the word 'Revolution'. I don't know the elements of the structural critique that is required

\footnotetext{
${ }^{5}$ The Times, 3 May 1966, p. 17, col. 3. Other signatories included John Dunn, Gillian Sutherland (as Gillian Thomas), Joan Robinson, Terry Eagleton and Raymond Williams. Overviews of the period, although with little about science, are in Mark Donnelly, Sixties Britain: Culture, Society and Politics, London: Routledge, 2013; and Arthur Marwick, The Sixties: Social and Cultural Transformation in Britain, France, Italy and the United States, 195874, Oxford: Oxford University Press, 1998.

${ }^{6}$ For Young's perspective on these issues see Robert M. Young, 'The historiographic and ideological contexts of the nineteenth-century debate on man's place in nature', in Mikuláš Teich and Robert M. Young (eds.), Changing Perspectives in the History of Science: Essays in Honour of Joseph Needham, London: Heinemann, 1973, pp. 344-438.
} 

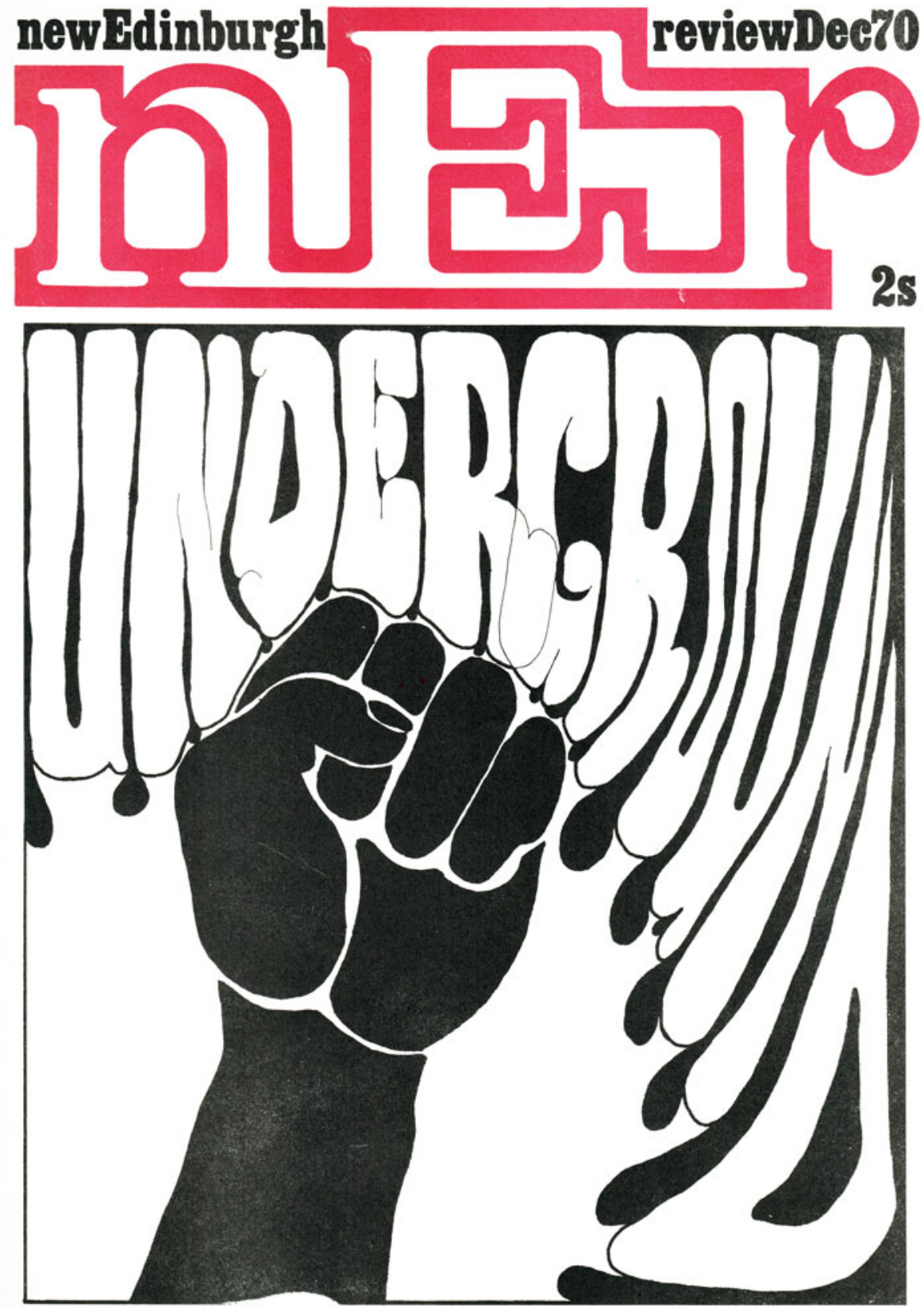

Figure I. New Edinburgh Review (December 1970) 10, cover of special issue on The Underground, with Young's essay on 'Functions of rock' as the lead article. The magazine, run by students at the University of Edinburgh, appeared every two months. Author's collection, reprinted by permission of Polygon, Birkitt Ltd. 
to achieve these changes, nor can I specify the role of rock and festivals in it. But I do know that we should be aware of an alternative interpretation of the function of rock and festivals, an interpretation which shows that we may very well be diverting our energies from achieving and implementing that critique. I'm not suggesting that we must choose between the music and the festivals on the one hand and hard-headed politics on the other. If we lose the spirit of the music, we lose the political and social and personal integration as well. But if we think the head revolution is enough on its own, we are leading ourselves into the same blind alley that earlier manifestations of the music have done. ${ }^{7}$

Just at this time Young was engaged in more direct forms of political action. He and his second wife Sheila Ernst became involved in the international campaign on behalf of Rudi Dutschke, a German student at Clare Hall who was deported from Britain by the Heath government as a danger to the state. While visiting Dutschke in Denmark in 1971, Bob and Sheila decided to form a commune in their house at 27 High Street in Chesterton, Cambridge, which embodied their aspiration towards revolutionary transformation. ${ }^{8}$

The rapidly changing situation led to unusual conjunctions. At the same time as Young had been campaigning for Dutschke, his article on 'The impact of Darwin on conventional thought' appeared in a collection of lectures published by no less staid an institution than the Society for the Promotion of Christian Knowledge. This essay was based on a talk he had given at the National Portrait Gallery in the winter of $1968 .^{9}$ For Young, participating in these diverse settings was part of a single process. 'History and long arguments' were not mystifications, but were essential to the movement's success. Just as music and social change could go hand in hand, carefully researched historical analysis could underpin efforts to change science, as part of the broader campaign for social justice. The key element was action. Young concluded the 'Afterthoughts' added to the New Edinburgh Review by noting that 'strategy and tactics must be appropriate to the objective conditions in Britain, and there is no substitute for political action, however much we should leaven them by the soul and values of rock music'. ${ }^{10}$ In terms of tactics, history of science was relevant, in an even broader way, in revealing the conceptual foundations for appropriate action. But history was useful only if it led to action.

What mattered for the committed historian of science was the history of ideas. This may come as a surprise to many who assume that intellectual history was the exclusive preserve of anti-Marxist defenders of the West during the Cold War. ${ }^{11}$ Yet all sides in the debate saw the foundations of science as conceptual. The dominance of this view was partly a response to the perceived crudity of 'vulgar' Marxism, in which the scientific superstructure grew directly out of the economic and technological base. That approach was usually typified by 'The social and economic roots of Newton's Principia', a paper by Boris Hessen from the Russian delegation at the famous International Congress of the History of Science and Technology in July 1931. Hessen's argument, although far from following a party line (he was executed in 1936), came to symbolize the failures of the Soviet Union under

\footnotetext{
${ }^{7}$ Bob Young, ‘The new nation?', Bath Festival of Blues \& Progressive Music (June 1970), pp. 29-33, 33.

${ }^{8}$ Martin Bernal, Geography of a Life, Bloomington, IN: Xlibris, 2012, Chapter 35.

${ }^{9}$ Robert M. Young, 'The impact of Darwin on conventional thought', in Anthony Symondson (ed.), The Victorian Crisis of Faith, London: Society for the Promotion of Christian Knowledge, 1970, pp. 13-35.

${ }^{10}$ Bob Young, 'Functions of rock', New Edinburgh Review, December 1970, pp. 4-14, 14, original emphasis. The particularities of the situation in Britain are addressed in Stuart Mitchell, 'You say you want a revolution? Popular music and revolt in France, the United States, and Britain during the late 1960s', Historia Actual (2005) 8, pp. 7-18.

${ }^{11}$ The limitations of this view are cogently presented in Robert Fox, 'Fashioning the discipline: history of science in the European intellectual tradition', Minerva (2006) 44, pp. 410-32.
} 
Stalin. ${ }^{12}$ Instead Young looked to the early Marx and writers such as György Lukács and Herbert Marcuse, who were at this time widely influential in the academic New Left.

Intellectual history was the chosen medium not only for the leading voices of liberal historiography (including Charles Gillispie and Thomas Kuhn in the United States, and Rupert Hall and Alistair Crombie in Britain) but equally for those who looked to see the establishment overthrown. The aim was to uncover The Metaphysical Foundations of Modern Physical Science (1924), to quote the title of a book by Edwin Burtt that shaped the intellectual trajectory of the postwar generation. This approach, developed by writers ranging from Alexandre Koyré and Emile Meyerson to Arthur Lovejoy and Alfred North Whitehead, involved analysing the concepts expressed by leading thinkers. The key participants were seen to be the handful of white male authors who wrote systematic treatises and dominated public discussion. The history of ideas first inspired Young while he was an undergraduate at Yale, and it motivated his entire intellectual career.

Soon after taking up a post in Cambridge as temporary assistant lecturer in history of biology in 1964, Young began teaching a six-lecture course on Science and Public Debate in Britain, 1830-1870 to small groups of final-year natural-science students and others, as part of a Special Paper under the auspices of the History Faculty. ${ }^{13}$ His approach crystallized as he worked on a (never-completed) study of the Victorian evolutionary debates, which allowed him to combine his formal role as a historian of the life sciences with his established interest in psychology and the human sciences. The most significant of his contributions, 'Malthus and the evolutionists', was delivered to the prestigious Stubbs Society in Oxford on 2 February 1968, two days after the Viet Cong launched the Tet offensive, a turning point in the war.

The paper's overarching claim was that biology and society belonged to the same debate. This meant drawing a wide net around the texts to be studied, with attention given to utopian writings by William Godwin and the Marquis de Condorcet, the natural theology of William Paley and the authors of the Bridgewater Treatises, the political economy of Thomas Chalmers and Thomas Malthus, and the social philosophy of George Combe and Herbert Spencer. Young then showed that the theory of evolution proposed in Darwin's On the Origin of Species and in the writings of Alfred Russel Wallace was directly in dialogue with these authors.

The most controversial aspect of Young's argument was that reading Malthus was constitutive for Darwin's formulation of natural selection, the keystone of modern biology. Especially for biologists, grounding Darwin's discovery in a controversial work of political economy was anathema. The Malthusian law famously stated that human population growth, unchecked, increases geometrically, while the supply of food can at most increase arithmetically. The result is dearth, death and a struggle for scarce resources. In Young's interpretation, Darwin removed any possibility of 'moral restraint' (delaying marriage) in softening the impact of Malthus's doctrine. He then extended it from humans to the whole living world, and used it to explain how new adaptations (and ultimately new species) came into being. In making his case, Young assembled a barrage of quotations in which Darwin expressed his debt to Malthus, starting with the autobiography, moving

\footnotetext{
${ }^{12}$ For discussion and further references see Simon Schaffer, 'Newton at the crossroads', Radical Philosophy (1984) 37, pp. 23-8; and Gary Werskey, 'The Marxist critique of capitalist science: a history in three movements?', Science as Culture (2007) 16, pp. 397-461.

${ }^{13}$ John Brooke recollects the course in an interview with Paul Merchant, 'Science and religion: exploring the spectrum', in National Life Stories, British Library, at https://sounds.bl.uk/related-content/TRANSCRIPTS/021TC1672X0008XX-0000A1.pdf, accessed 30 November 2020. For the correct date of Young's appointment as assistant lecturer see Cambridge University Reporter (1 October 1964) 95, p. 13; the post was advertised in the Reporter (22 April 1964) 94, pp. 1541-2. I acknowledge the assistance of Kathryn Jennings in the Cambridge University Library for all references to this source.
} 
backwards in time through the Origin and other published works, and ending with passages from manuscript notebooks that had only recently been transcribed and published. $^{14}$

The claim about natural selection was the pivotal move in uniting social and biological thought in a shared context. Young pointed out that writers on the left had traditionally prized apart Darwin and Malthus. In this tradition, Darwin was a hero of scientific socialism: as Marx had written to the German socialist Ferdinand Lasalle, the Origin 'provides a basis in natural science for the historical class struggle'. ${ }^{15}$ In contrast, Malthus was condemned as a 'bourgeois fraud' who had naturalized the faults of a political system based on capitalism. Young profoundly disagreed with this separation. ${ }^{16}$ As he summed up his argument:

Instead of seeing Malthus as an influence outside of biology, I should like to indicate the ways in which his theory and its assumptions about nature were at once pervasive in the biological literature of the first decades of the century and a part of an ongoing debate within natural theology which was at least as important to Darwin and Wallace as the question of the mechanism of evolution. Finally, I want to suggest that the distinction between social and biological issues - which was, in turn, based on the distinction between man and animals which evolutionary theory was supposed to break down from 1859 onwards - was broken down in principle well before the turn of the century. ${ }^{17}$

The essay concluded by carrying the story to the present day. As Young noted with uncharacteristic indirectness, 'it is not unlikely that a future historian will find that the neat division between biological and social science which most current scientists believe to have been established, is less absolute than it now appears' ${ }^{18}$ The key issue was purity. Western scientists characteristically complimented themselves on separating biology from politics and social science, in contrast with the situation in totalitarian regimes such as the Soviet Union, where scientific theories developed in line with ideological orthodoxy. The standard example of the dangers of mixing science with politics involved the Soviet regime's support for the melioristic theories of inheritance advocated by Trofim Denisovich Lysenko. Young, however, believed that such cases were aberrations. This was not because science was otherwise always pure, but because the 'Lysenko affair' involved grotesque attempts by the state to enforce scientific orthodoxy. Imprisonment, torture and murder were not the only means through which politics could shape science. Young argued that the Soviet case could not be used to claim that 'well-attested scientific findings' such as the structure of DNA were beyond ideology. ${ }^{19}$

Within biology, Darwin was a critical figure during the 1960s, often treated as though he was a contemporary. These years were the high point of Francis Crick's 'central dogma' and the neo-Darwinian synthesis, which ruled out any form of somatic inheritance and

\footnotetext{
${ }^{14}$ Young, op. cit. (4), pp. 125-30. The relevant passages first appeared in Gavin de Beer, Charles Darwin: Evolution by Natural Selection, London: Nelson, 1963, pp. 99-100. See also Gavin de Beer, M.J. Rowlands and B.M. Skramovsky (eds.), 'Darwin's notebooks on the transmutation of species. Part VI. Pages excised by Darwin', Bulletin of the British Museum (Natural History) Historical Series (1967) 3(5), pp. 129-76.

${ }^{15}$ K. Marx to F. Lasalles, 16 January 1861, in Marx-Engels Collected Works, vol. 41, Moscow: Progress Publishers, 1975, pp. 246-7, 138-9

${ }^{16}$ Young, op. cit. (4), pp. 138-9.

17 Young, op. cit. (4), pp. 110-11.

${ }^{18}$ Young, op. cit. (4), p. 140.

${ }^{19}$ Young developed this perspective in more detail in Robert M. Young, 'Getting started on Lysenkoism', Radical Science Journal (1978) 6-7, pp. 81-105.
} 
stressed the comprehensive power of natural selection over all other evolutionary mechanisms. The emergence of a belief in the biological determinants of human behaviour gave a 'hard' interpretation of Darwin's theory a unique significance. ${ }^{20}$ This was also the decade following the centenary of the Origin in 1959, which revived Darwin's reputation and sparked the enduring fascination in his life and writings. As the historian of science David Kohn later noted, 'only after biologists legitimated Darwin did historians rush to study him'. ${ }^{21}$ Young, of course, was not out to legitimate Darwin - far from it - but rather to use the remarkable prominence of the theory of natural selection to tackle current issues in the relations of biology and society, what Theodore Roszak would term 'the grizzly callousness of social Darwinism'. ${ }^{22}$ Understanding the genesis of natural selection thus held a key to understanding science in society.

Malthus was the perfect battering ram. The argument that unchecked population growth would ultimately outstrip food supply had been a flashpoint for controversy since its inception, but never more so than in the period in which Young's article appeared. $^{23}$ The postwar years through the mid-1970s have been identified as the 'Malthusian moment', with a resurgence of interest in the problems his work had posed. In the United States, concerns about global overpopulation catalysed mass environmental movements. ${ }^{24}$ In Britain, however, this 'green Malthus' had scarcely emerged, with debate centred instead on questions of religion, birth control and economic analysis. $^{25}$

The prominence of the Essay in these polemics gave Malthus a fresh notoriety. His work was central to the distinguished Oxford geneticist Cyril Darlington's The Evolution of Man and Society (1969), which appeared soon after Young's Past and Present essay. In this widely discussed book (which Young furiously condemned in the New Statesman) Darlington reduced human history to biology, with selection between races and classes as the driving force of evolutionary progress. He ranked Malthus high in his 'succession of pioneers', although this was strictly for the mathematical law of population, which had to be disentangled from the theological and social views of an Anglican parson. The discovery of natural selection ('Darwin's rider' to the Malthusian law) had revealed competition for limited resources as the underlying principle of biology. ${ }^{26}$ Malthus, in Darlington's view, thus provided the foundations for a racist history of humanity.

Most evolutionary biologists, challenged by the ascendency of molecular biology, were determined to demonstrate the purity of their science, so the influence of Malthus on Darwin was downplayed just as it had been among the Marxists. The centennial celebrations of the Origin in the late 1950s made the wealthy embryologist Sir Gavin de Beer the most influential commentator on Darwin in the English-speaking world. De Beer,

\footnotetext{
${ }^{20}$ S.J. Gould, 'The hardening of the modern synthesis', in Marjorie Grene (ed.), Dimensions of Darwinism: Themes and Counterthemes in Twentieth-Century Evolutionary Theory, Cambridge: Cambridge University Press, 1983, pp. 71-93; and Erika Lorraine Milam, Creatures of Cain: The Hunt for Human Nature in Cold War America, Princeton, NJ: Princeton University Press, 2019.

${ }^{21}$ David Kohn, 'Introduction: a high regard for Darwin', in Kohn (ed.), The Darwinian Heritage, Princeton, NJ: Princeton University Press in association with Nova Pacifica, 1985, pp. 1-5, 2.

${ }^{22}$ Roszak, op. cit. (1), p. 101.

${ }^{23}$ Robert J. Mayhew, Malthus: The Life and Legacies of an Untimely Prophet, Cambridge, MA: Harvard University Press, 2014.

${ }^{24}$ Thomas Robertson, The Malthusian Moment: Global Population Growth and the Birth of American Environmentalism, New Brunswick, NJ: Rutgers University Press, 2012.

${ }^{25}$ Robert J. Mayhew, 'The publication bomb: the birth of modern environmentalism and the editing of Malthus's Essay', in Mayhew (ed.), New Perspectives on Malthus, Cambridge: Cambridge University Press, 2016, pp. 240-66, esp. 259-60.

${ }^{26}$ C.D. Darlington, The Evolution of Man and Society, London: George Allen and Unwin, 1969, pp. 61, 680. Robert M. Young, 'Understanding it all', New Statesman (26 September 1969) 78, pp. 417-18.
} 
who drove daily in his Rolls Royce to the British Museum (Natural History) even after he had ceased to be its director, consistently maintained that Darwin was untainted by Malthusian political economy or natural theology. The great naturalist's accomplishment achieved in splendid isolation and purely on the basis of observation-was to move evolutionary theorizing into the realm of science. Without Darwin, de Beer stressed, evolutionary theorizing 'was ringing wet with politics'. ${ }^{27}$

De Beer's self-confessed status as a 'high-priest of Darwin' was crowned in 1960 with publication in the Bulletin of the British Museum (Natural History): Historical Series of the transmutation notebooks, the records of Darwin's thoughts on species in the crucial years after the Beagle voyage. Frustratingly, this edition was incomplete, as Darwin had excised pages for later use, and among those missing appeared to be the record of his first reading of Malthus's Essay. In October 1962, de Beer was present when a black metal box of Darwin's papers, previously in possession of the family, was hammered open. As was his usual practice, de Beer delegated the reading, sorting and transcribing of these extraordinarily complex materials to an Austrian-born secretary at the British Museum (Natural History), Maria Skramovsky. As de Beer acknowledged, it was Skramovsky who 'found, recognized and showed me' the page from 28 September 1838 recording Darwin's initial reaction to Malthus's Essay. ${ }^{28}$ The page she found was first quoted by de Beer in his 1963 biography of Darwin, and soon afterwards was the centrepiece of an article by him in New Scientist, outlining 'How Darwin came by his theory of natural selection'.

With triple underlining and extensive interlineation, the notebook page was clearly significant, and Young's article would quote it as 'unequivocal evidence of Malthus's rôle in the actual formation of Darwin's theory'. ${ }^{29}$ We do not know what Skramovsky thought about her discovery, but for de Beer and other biologists, the explanation remained unchanged. Malthus had no constitutive part in the origins of natural selection; the Essay provided nothing more than an enhanced appreciation of the mathematics of selection pressure - as well as an unproven 'banal slogan' about geometrical versus arithmetical rates of increase. ${ }^{30}$ To the end of his life de Beer continued to resist any significant role for Malthus, and he vetoed publication of Darwin's notebooks on metaphysics and mind, seeing these as outside proper scientific interests. Skramovsky had wanted her transcriptions to appear as a follow-up to the notebooks on species, but was overruled. ${ }^{31}$

As in the natural sciences, Darwin was recognized in the humanities as a significant figure, although the analysis of his work typically fell into the chasm separating what

27 Gavin de Beer, 'How Darwin came by his theory of natural selection', New Scientist (23 January 1964) 21, pp. 216-18, 217. 'Perched on a pile of cushions, [de Beer] daily sallied forth from the Museum in his Rolls Royce into the tide of traffic with an unassailable (and in the event justified) faith that it would part at his coming'. William T. Stearn, The Natural History Museum at South Kensington, London: William Heinemann, 1981, p. 339.

${ }^{28}$ De Beer, op. cit. (27). Born in Vienna in 1914, Bertha Maria Skramovsky had emigrated to Britain and after the Second World War became a naturalized citizen. She worked initially as a housekeeper, but her language skills and evident abilities gained her employment in London in increasingly senior clerical posts at the museum. For the birthdate see National Archives, Kew, Piece Number Description 086: Internees at Liberty in UK 19391942: Sk-Spe. Skramovsky was naturalized in 1947 (see London Gazette, 21 November 1947), retired from the museum at the end of 1967, married in 1970 and died on 11 December 2006 at the age of ninety-two. I am grateful to Kathryn Rooke of the Natural History Museum, and to Anne Secord, for information about Skramovsky.

${ }^{29}$ Young, op. cit. (4), p. 127.

${ }^{30}$ De Beer, op. cit. (27), p. 218.

${ }^{31}$ Sandra Herbert, 'The Darwinian revolution revisited', Journal of the History of Biology (2005) 38, pp. 51-66, 55. Only in 1974, two years after de Beer's death, did the M and N notebooks appear in an edition by Paul Barrett. For an overview of the history of the manuscripts see Sydney Smith, 'Historical preface', in Paul H. Barrett, Peter J. Gautrey, Sandra Herbert, David Kohn and Sydney Smith (eds.), Charles Darwin's Notebooks, 1836-1844, London and Ithaca, NY: British Museum [Natural History] and Cornell University Press, 1987, pp. 1-5. 
the novelist C.P. Snow had identified in 1959 as 'the two cultures'. During the years immediately after 1959, no professionally trained historians of science in Britain were seriously studying Darwin or the development of evolutionary theory. ${ }^{32}$ In Cambridge, the history and philosophy of science, as part of the Natural Sciences Tripos, stressed rigorous analysis of concepts in the physical sciences and in philosophy, and technical work on the history of astronomy. The subject was not yet conducted in a distinct department, but through a 'committee' with members scattered across the university. Young was initially placed in the Department of Experimental Psychology, but he looked to the History Faculty, then dominated by historians of politics and religion, for intellectual orientations. The history of political thought as developed by Quentin Skinner, John Dunn and others although seen by Young as a crucial resource - in retrospect can be seen to have almost completely ignored the natural sciences. ${ }^{33}$

There were, however, places in Cambridge where the research Young was advocating could be pursued, such as a path-breaking seminar series in 1968-9 at the King's Research Centre. This monthly seminar, which brought together many future leaders of the field and a remarkable array of approaches, was co-organized with Piyo Rattansi, who had moved from Leeds to Cambridge on a four-year fellowship at King's which had been brokered by Young. Soon after his appointment as assistant lecturer, Young had learned about Rattansi's work on seventeenth-century English scientific debates from a key mentor, the sinologist Joseph Needham, who was based in Gonville and Caius College. ${ }^{34}$ Young also maintained good relations with the History Faculty, and opposed combining history of science with philosophy of science in a separate department, as occurred in $1972 .{ }^{35}$ He was friendly with Raymond Williams in English, and Martin Richards in Social and Political Sciences. But most of these connections proved fragile, as when he and John Dunn fell out over Marxism. As another one-time associate Martin Bernal recalled, Young 'achieved a great deal but has antagonized almost everybody he encountered'. ${ }^{36}$ The person with the closest intellectual interests would have been John Burrow, whose doctoral thesis provided the basis for the still standard Evolution and Society: A Study in Victorian Social Theory (1966), which Young praised in the Cambridge Review and assigned to students. ${ }^{37}$ Burrow, however, had earlier failed to obtain a position in the faculty, leaving Young as the only person in Cambridge pursuing the intellectual history of the modern period.

The situation was more promising for seventeenth-century studies and elsewhere in the country, largely through approaches pioneered by Rattansi, J.E. McGuire and Charles Webster at Leeds and the Marxist seventeenth-century historian Christopher Hill and others at Oxford. History was changing rapidly, with a stress on hitherto marginalized groups and the critical revaluation of traditional narratives. Notably, it was at Oxford, not Cambridge, that 'Malthus and the evolutionists' had its main public airing

\footnotetext{
32 Bert James Loewenberg, 'Darwin and Darwin studies, 1959-63', History of Science (1965) 4, pp. 15-54, surveys the work being carried out.

${ }^{33}$ For Young's view of the situation in Cambridge see Young, op. cit. (6). For other perspectives see Gerd Buchdahl, 'Twenty-five years of history and philosophy of science at Cambridge', Cambridge Review (1989) 10, pp. 167-71; and the overview in Anna-K. Mayer, "'I have been very fortunate": brief report on the BSHS Oral History Project: “The history of science in Britain, 1945-65”, BJHS (1999) 32, pp. 223-35.

${ }^{34}$ Raphael Uchôa, interview with Piyo Rattansi, Circumscribere (2019) 23, pp. 1-76, 16-17, on the seminar see 48-9.

${ }^{35}$ Fox, op. cit. (11), p. 425.

${ }^{36}$ Bernal, op. cit. (8), Chapter 35, n.p.

${ }^{37}$ Robert M. Young, review of J.W. Burrow, Evolution and Society, Cambridge Review (1967) 89, pp. 409-11. The book is on the reading list for the course, as evidenced by notes made at the time by Patrick Parrinder, who kindly provided a full transcript (personal communication, 18 March 2020).
} 
in 1968 at the Stubbs Society. Young's name had been put forward by the historian of science Alistair Crombie, who quickly regretted his suggestion. Oxford was also the home of Past and Present, and the assistant editor Timothy Mason, a Marxist historian of Nazi Germany, invited Young to submit to the journal after attending the seminar. ${ }^{38}$ Among historical periodicals, Past and Present was unusual in being run by a collective board, combining Marxists such as Hill and Mason and liberals such as Lawrence Stone. ${ }^{39}$ Rapidly emerging as the most prestigious journal of its kind in the English-speaking world, it was publishing not only material from the left, but also occasional pieces on the history of science, although the latter had exclusively dealt with seventeenth-century topics.

'Malthus and the evolutionists' - together with the thesis book on Mind, Brain and Adaptation in the Nineteenth Century (1970), and the other essays on 'man's place in nature' from this time - established Young's reputation within the academy. This was just at the moment, however, when he became increasingly frustrated by the limitations of a university career. Young had failed to gain a permanent university lectureship when one was advertised in 1967, despite his evident promise at this early stage. ${ }^{40}$ Although in 1971 he was appointed to a term-limited post as director of a Wellcome-funded Unit for the History of Medicine in what soon became the Department of History and Philosophy of Science, this proved a source of conflict and administrative logjams. By this point Young had already begun the work that led to the founding of the Radical Science Journal and the British Society for Social Responsibility in Science. In 1974 he made a brave decision to pursue these new initiatives, move to London and abandon the security of university and college positions. ${ }^{41}$ Young subsequently produced science programmes for television, began several important journals, founded two publishing companies, and eventually studied to become a practising psychiatrist. While continuing actively to write and publish, he increasingly left the history of science behind.

\section{Changing perspectives}

If Young 'moved on', to use one of his favourite phrases, his central argument about Darwin and Malthus remained available in the pages of Past and Present, where it was widely cited and read. The essay was reprinted for students in a series produced by the American publisher Bobbs-Merrill, which indicates just how extensively it was used in teaching. In 1985 it was republished in Darwin's Metaphor: Nature's Place in Victorian Culture, which collected Young's articles from 1969 to $1973 .{ }^{42}$ Three settings were crucial for the reception of Young's argument: historical studies of Charles Darwin, the social history of nineteenth-century British science, and the emergence of sociologically inspired studies of scientific practice.

'Malthus and the evolutionists' appeared at an early but pivotal period in the scholarly re-evaluation of significant figures such as Newton, Galileo, Freud and Darwin. This

\footnotetext{
${ }^{38}$ Anna-K. Mayer, interview with Robert M. Young, 10 Feb. 1998, British Society for the History of Science Oral History Project, Special Collections, Leeds University Library. Cited with the permission of the President and Council of the British Society for the History of Science.

${ }^{39}$ Christopher Hill, R.H. Hilton and E.J. Hobsbawm, 'Origins and early years', Past and Present (1983) 100, pp. 3-14; and Jacques Le Goff, 'Later history', Past and Present (1983) 100, pp. 14-28.

${ }^{40}$ Cambridge University Reporter (1 March 1967) 97, pp. 1002-3. Martin Rudwick was appointed to the position.

${ }^{41}$ Young resigned from his King's fellowship and his post as assistant director of research in the Wellcome Unit, effective 31 December 1974. For the date, which is incorrectly stated in most sources, see 'University offices vacated during the academical year 1974-75', Cambridge University Reporter (8 Oct. 1975) 106, p. 84.

${ }^{42}$ The essays (with revisions and additions) were collected in Robert M. Young, Darwin's Metaphor: Nature's Place in Victorian Culture, Cambridge: Cambridge University Press, 1985.
} 
movement was delayed in the history of political economy: the increased public prominence of Malthus had been accompanied by editions of his writings and occasional articles, but the only book-length account of the debate remained Kenneth Smith's largely descriptive and anti-Malthusian The Malthusian Controversy of $1951 .^{43}$ In contrast, the 1959 centennial of the Origin had sparked an explosion of celebratory publications about Darwin. Even so, serious research into primary sources had barely begun. Indications of the riches of the manuscript collections, deposited mainly in the University Library in Cambridge, were available in publications by Darwin's granddaughter, Nora Barlow, of the autobiography and various documents from the Beagle voyage, and in the piecemeal appearance of the transmutation notebooks between 1959 and 1967. Access to the collection was mediated by the embryologist Sydney Smith and the archivist Peter Gautrey. A succession of scholars, largely from North America, began to make the pilgrimage to the Fens that marked one as a true expert. ${ }^{44}$

The examination of this rich archive by professionally trained historians was transformative. No longer was it easy to say, as de Beer had done (and continued to maintain), that Darwin already had the theory of natural selection before reading Malthus in September 1838. Nor did it make sense to claim, as passages in the autobiography and in letters can be interpreted - that Darwin had seen artificial selection in action but needed to understand how to apply it to nature. Instead, the reading of Malthus's Essay led Darwin to realize the power not just of competition between species, but also of competition between individuals of the same species. This argument, made by Sandra Herbert in her Brandeis PhD dissertation of 1968 and a brief article in 1971, had the potential to give Young's broader claims vital specificity and content. ${ }^{45}$

The other key revelation, developed in the late 1970s and early 1980s especially by David Kohn, was that Darwin had 'a theory to work by' based on reproduction, well before the reading of Malthus. Darwin was searching the literature on breeding, not to find an analogue in nature for artificial selection, but to answer questions about generation, growth and heredity. On reading the Essay, Darwin initially expressed the force of intra-species competition through a violently mechanical metaphor of wedging; only in the following months did he reconceptualize his new vision in terms of softer analogies between 'artificial' and 'natural' selection. ${ }^{46}$

'Malthus and the evolutionists' came out remarkably well from these studies. As Kohn wrote in a phrase that Young liked to quote, 'The work of one recent commentator, Robert M. Young, stands out as nearly definitive'. ${ }^{47}$ Yet in significant respects Young never appreciated the potential of what authors such as Kohn and Herbert had done for the historiographic politics of the Malthus question. While quoting the relevant passages and

\footnotetext{
${ }^{43}$ Mayhew, 'The publication bomb', op. cit. (25), p. 262 n. 13, speaks of 'an explosion of interest', but the volume of scholarly historical publication before Patricia James's Population Malthus: His Life and Times, London: Routledge, 1979, appears modest.

${ }^{44}$ For an insightful analysis of Young's relation to these later writings see Ingemar Bohlin, 'Robert M. Young and Darwin historiography', Social Studies of Science (1991) 21, pp. 597-648. The literature is summarized in David Oldroyd, 'How did Darwin arrive at his theory? The secondary literature to 1982', History of Science (1984) 22, pp. 325-71. It is viewed in wider contexts in John C. Greene, 'Reflections on the progress of Darwin studies', Journal of the History of Biology (1975) 8, pp. 243-73; and in Piers J. Hale, 'Finding a place for the anti-Malthusian tradition in the Victorian evolutionary debates', in Mayhew, New Perspectives on Malthus, op. cit. (25), pp. 182-207. The most valuable general survey (up to the mid-1980s) remains Antonello La Vergata, 'Images of Darwin: a historiographic overview', in Kohn, The Darwinian Heritage, op. cit. (21), pp. 901-72.

${ }^{45}$ Sandra Herbert, 'The logic of Darwin's discovery', Brandeis University PhD dissertation (1968); Herbert, 'Darwin, Malthus and selection', Journal of the History of Biology (1971) 4, pp. 209-17.

${ }^{46}$ David Kohn, 'Theories to work by: rejected theories, reproduction, and Darwin's path to natural selection', Studies in History of Biology (1990) 4, pp. 67-170, 142.

${ }^{47}$ Kohn, op. cit. (46), p. 142.
} 
stressing the relevant contexts, Young had been surprisingly vague on the critical issue of what Darwin took away from the Essay: 'It seems that Malthus legitimized the idea of a law of struggle, impressed Darwin with the intensity of struggle, and provided a convenient natural mechanism for the changes which Darwin was studying in the selection of domesticated varieties'. ${ }^{48}$ From this perspective, Malthus gave new emphasis to the concept of struggle, already familiar from other works; but this was a change of degree rather than of kind. And Young also expressed the traditional view that before Malthus Darwin had no theory, but instead was searching for a natural analogy with artificial selection.

In other words, at this level of detail 'Malthus and the evolutionists' simply repeated the standard line familiar from de Beer's Darwin biography. Young admitted as much in the mid-1980s, noting, "my own reading of what Darwin "got" from the Essay is remarkably close' to what de Beer and other biologists had said. What mattered to Young was the broader context. ${ }^{49}$ However, the existence in the notebooks of a pre-Malthusian theory for speciation, and the distinction between 'inter-specific' and 'intra-specific' competition, were not just details, but ways of placing individual competition and capitalist political economy at the heart of the theory. Although de Beer, Mayr and other biologists continued as sceptics, the broader significance of Malthus was suddenly harder to dismiss, which made Young's argument much more directly significant. ${ }^{50}$

For all that, the turn to manuscripts had major downsides. The work in what was becoming known as the 'Darwin industry' became increasingly esoteric, inward-looking and out of touch with more general trends in science studies in being resolutely focused on a single individual. As Young reflected after attending a major meeting organized by Kohn at the Villa di Mondeggi in Florence in 1982,

The zeal with which current scientist-historians seek to separate Darwin's genius and achievements from the work, ideas, and influences of Spencer, Chambers, and Wallace seems to betray a pathetic, sycophantic hagiography - Great Man history which I thought was waning in the history of science, as historians of science thought of their discipline in terms of the history of ideas, the history of culture, and the history of society. Indeed, one distinguished biologist-historian [Ernst Mayr] concluded his comments by saying that Darwin was the author of 'the greatest and most universal revolution ever experienced in the history of human thought'. I found myself asking, why do we defer to great men? Why do we defer to working scientists who are part-time historians? Why do we defer to great men in the history of science? Why do we not consider the social processes of scientific change in their broadest contexts? Where have these questions gone in the past decade? ${ }^{51}$

Although close studies of the manuscripts often ended up supporting the connection between Malthus and Darwin, specialist monographs and long articles in the Journal of the History of Biology and the annual Studies in History of Biology seemed to have lost interest in the metaphysical foundations of a debate about humans in nature that extended to the present day. Historians of biology, in their attempts to establish rigour and appease

\footnotetext{
${ }^{48}$ Young, op. cit. (4), p. 130.

${ }^{49}$ Robert M. Young, 'Darwinism is social', in Kohn, The Darwinian Heritage, op. cit. (21), pp. 609-38, 634. As is clear from the Past and Present article (p. 71), Young derived much of his understanding of the transmutation notebooks from conversations with Sydney Smith, who (like de Beer) did not see Darwin's reading of Malthus as a decisive turning point.

${ }^{50}$ For a thorough discussion of this issue see Bohlin, op. cit. (44), pp. 627-34. Young explicitly rejected the significance of any of these distinctions in 'Malthus on man: in animals no moral restraint', in Brian Dolan (ed.), Malthus, Medicine, and Morality: 'Malthusianism' after 1798, Amsterdam, Rudolfi, 2000, pp. 73-91.

51 Young, op. cit. (49), p. 633.
} 
practising scientists, had too often overlooked the political context in which their work was embedded. Young would not have been surprised to know that Mayr, an honoured presence at the Florence meeting, privately supported Darlington's view that human history was the product of biological competition between lesser and more advanced biological races. As Mayr had written in a letter to Darlington,

I am delighted you have said all these things which are so true but which are simply suppressed in the 'egalitarian' mass media ... I am frank to say, your bias, or I should say government policies based on your bias, should promise a far better future for mankind than the ruling bias. ${ }^{52}$

Young collected his old essays directly in response to the Florence gathering. By his own admission he had left the history of science well behind, and ironically, his academic reputation as a historian became retrospectively limited to that of a leading 'Darwin scholar'. ${ }^{53}$ His jaundiced view was coloured by the fact that the Darwin/Malthus literature was almost the only subject in nineteenth-century science he tracked closely. He was disappointed by its increasing narrowness and lack of political bite. Although vastly more was known about Darwin, the literature seemed-sometimes unwittingly, sometimes not - simply to reinforce notions of genius and singular greatness.

There was, of course, a lot else going on. Although there were only limited indications of this in Florence, the institutional and social history of British science was blossoming. This work was produced by a diverse array of participants spread across the English-speaking world, especially in the north of England, as part of a much broader move to cultural history among historians generally. ${ }^{54}$ The resulting studies vastly increased the range of participants in British science, and offered for the first time a secure institutional framework for understanding their activities and status. ${ }^{55}$ The dominance of a few leading men was no longer a taken-for-granted feature of intellectual life in the nineteenth century, but understood as a product of the individualistic bias of British scientific culture.

A later generation carried this project further, dismantling monolithic conceptions of 'popular science' and revealing new spaces for science populated by women, artisans and other hitherto marginalized groups. After these writings, no one could say, as Young had, that popular phrenology and mechanics' institutes could be demarcated from the study of an 'intelligentsia'. ${ }^{56}$ (He had never even considered the idea of women, other than George Eliot, playing any significant role.) His insistence that the agenda should be 'broadened' to include figures such as Herbert Spencer and Robert Chambers looked out of touch, even in the very specific context of research into Darwin. ${ }^{57}$

\footnotetext{
${ }^{52}$ Mayr to Darlington, 28 November 1978, quoted in Solomon Harman, The Man Who Invented the Chromosome: A Life of Cyril Darlington, Cambridge, MA: Harvard University Press, 2004, p. 261.

${ }^{53}$ See the editor's title of the obituary by Roger Smith, 'Robert M Young: science historian and Darwin scholar who wielded great influence on the cultural left', The Independent, 19 August 2019. John Durant's assessment of Young as 'the world's leading Darwin scholar' is prominently featured on Young's website at www.psychoanalysis-and-therapy.com/rmyoung/pubs.html, accessed 18 April 2020.

${ }^{54}$ For the development of cultural history in relation to social history see William H. Sewell, 'The political unconscious of social history', in Sewell, Logics of History: Social Theory and Social Transformation, Chicago: The University of Chicago Press, 2005, pp. 22-80.

${ }^{55}$ David Philip Miller, 'The social history of British science: after the harvest?', Social Studies of Science (1984) 14, pp. $115-35$.

${ }_{56}$ Robert M. Young, 'Natural theology, Victorian periodicals, and the fragmentation of a common context', in Colin Chant and J.R. Fauvel (eds.), Darwin to Einstein: Historical Studies on Science and Belief, London: Longman/Open University Press, 1980, pp. 69-107, 74.

${ }^{57}$ One way in which a wider perspective took hold was, paradoxically, through complete publication of the notebooks in 1987 and the volumes of the Darwin correspondence from 1985. For this point see Evelleen
} 
As John Christie said in reviewing Darwin's Metaphor in 1988, there was no particular reason why 'heavy-duty social history' could not be combined with a 'broad-based intellectualist historiography'. ${ }^{58}$ Young did know about the transformation of the social history of Victorian science, but from his perspective it was bound always to be peripheral; with characteristic candour, he admitted to not having read Jack Morrell and Arnold Thackray's Gentlemen of Science: The Early Years of the British Association (1981), probably the most significant work in this tradition. ${ }^{59}$ He had always made it clear that what mattered were the writings of 'the intelligentsia', not what he explicitly dismissed as 'the social history of ideas conceived as the study of low-brow popular opinion'. ${ }^{60}$ In fact, Young's phrenologically limited focus was always even more specific, on some twenty 'major thinkers' and 'major' reviews of their works. His essays referred extensively to the periodical press, but never discussed, say, something so fundamental as the political orientation of the Edinburgh Review compared with the Quarterly. Young's polemical farewell to his Cambridge years, published in 1973, pointed towards the need for what he called a 'social intellectual history'. ${ }^{61}$ This, however, remained an aspiration, in important respects not easy to reconcile with his overall political project.

Within the history of science generally in the 1970s and 1980s, even more important than the retooling of the social history of science was a move from the history of ideas to the history of practice. This was a political change of tactics, as analysis moved from science as ideology to science as work. ${ }^{62}$ The inspiring sociological studies were about life in laboratories, showing how the contents of science could be the subject of sociological analysis. ${ }^{63}$ From Young's perspective, as with many on the left who emerged from the debates in the 1960s, the new sociology of knowledge only rarely put to the fore questions of overt political use and ideology. Partly for that reason, this work never seemed particularly important to Young, even as his own concerns moved towards studies of the labour process. ${ }^{64}$ He never applied these approaches to the Victorian debates, nor did he appreciate work that did this.

Yet the new methods did have a political foundation. It had simply proved too easy to see the 'social' as an optional add-on. ${ }^{65}$ Thus Malthus could be seen as critically important to the making of Darwin's evolutionary theory, but could arguably not carry the ideological baggage of political economy and its draconian applications in the 1830s,

Richards, 'Democratizing Darwin', Annals of Science (1992) 52, pp. 509-17, 512. The Darwin Correspondence Project, begun in 1974 by the American philosopher Frederick Burkhardt with the assistance of the zoologisthistorian Sydney Smith and a small team of researchers, proposed to issue only letters from Darwin, but was funded by the National Science Foundation on the condition that it published letters to him as well. This changed what would have been a monument to a great man into a resource for understanding the Victorian debates, involving some two thousand correspondents from across the world.

${ }^{58}$ J.R.R. Christie, review of R.M. Young, Darwin's Metaphor, Social Studies of Science (1988) 18, pp. 187-9, 188.

${ }^{59}$ Young, op. cit. (42), p. 365.

${ }^{60}$ Young, op. cit. (56), p. 74.

${ }^{61}$ Young, op. cit. (6), pp. 351-2. For recognition that his own work had not accomplished this integration see Bob Young, 'Desmond and Moore's Darwin: a critique', Science as Culture (1994) 4, pp. 393-424, 399.

${ }^{62}$ Agar, op. cit. (1), pp. 594-5, cites Young as providing 'a masterclass in the new sociology of science' at the 1970 meeting of the British Society for Social Responsibility in Science, but his emphasis was very different than that being developed in Edinburgh, even if some of the motives were related.

${ }^{63}$ For these developments see Jan Golinski, Making Natural Knowledge: Constructivism and the History of Science, 2nd edn, Chicago: The University of Chicago Press, 2005.

${ }^{64}$ See, for example, Young, 'Science is a labour process', in Science for People (1979) 43-4, pp. 31-7; and Turchetti, op. cit. (2), pp. 84-7.

${ }^{65}$ For example, see the autobiographical preface by Steven Shapin to Daniel S. Greenberg, The Politics of Pure Science, 2nd edn, Chicago: The University of Chicago Press, 1999; and Steven Shapin's comments on Young in 'History of science and its sociological reconstructions', History of Science (1982) 20, pp. 157-211, 178-9. 
let alone provide an argument for radical action today. Such connections could scarcely bear the weight of Young's increasingly frustrated and repetitive glosses on his early work. As Frank Turner complained in reviewing Darwin's Metaphor, 'that commentary really has little or nothing to do with what Young has written or taught us'. ${ }^{66}$

Even more critically, too much of Darwin's science seemed hard to fit into an ideological template. What about writings on barnacles, orchids and coral reefs, the research that gave Darwin's evolutionary theory its authority and power? This is a point that Thomas Kuhn had raised in discussing the problem soon after the Past and Present essay appeared, and one that Jonathan Hodge pressed at the Florence meeting. Young always resisted the idea of a 'scale' of purity moving from science to ideology, and repeatedly castigated Edward Thompson and others for separating the polemicist Thomas Henry Huxley from the supposedly neutral scientist Darwin. ${ }^{67}$ However, Young's own unwillingness to look closely at scientific work in the laboratory and field tended towards precisely that conclusion. He did not read any papers in zoological, botanical and natural-history journals, so these arenas seemed outside the discussion. Thus in dealing with geology, Young was willing to adopt Martin Rudwick's view that stratigraphy, surveying and other subjects could be studied within the parameters of a well-demarcated disciplinary community, insulated from considerations of economic management or imperial control. ${ }^{68}$ Only when the documents revealed specifically religious, political or otherwise 'ideological' concerns did Young show any interest. As Kuhn commented on the paper, 'far from being a barrier breaker, it belongs to a standard historiographical tradition which has done much to preserve the very separation Young deplores' ${ }^{69}$

For many historians of science writing in light of the sociological work unintentionally inspired by Kuhn's Structure of Scientific Revolutions (1962), the key political imperative was to tackle the detailed contents of science. There were important moves towards this during the mid-1970s, as in studies of laboratory research schools by Jack Morrell and Gerald Geison, and early interest in the sociological work of Harry Collins, particularly his 1975 article on the replication of experiments in gravity waves, 'The seven sexes'. ${ }^{70}$ The key developments in bringing scientific practice and social history together for the nineteenth century date from Steven Shapin's classic paper in the Sociological Review of 1979 on phrenology, tellingly titled 'The politics of observation'. Shapin's previous essays in this area had mapped support for phrenology onto ideology and social class, using models of interest theory combined with work in prosopography. The new work looked at practices of observation and dissection. By 1982 Shapin had brought together a host of studies under this umbrella in an influential paper, "History of science and its sociological reconstructions'. ${ }^{71}$

\footnotetext{
${ }^{66}$ Frank M. Turner, review of Robert M. Young, Darwin's Metaphor, Isis (1986) 7, pp. 727-8, 728.

${ }^{67}$ Young's remarks on the question of a scale would appear to be somewhat contradictory, but see Young, op. cit. (6), p. 194.

${ }^{68}$ Young, op. cit. (6), pp. 364-5. Rudwick later wrote essays that did place geology in wider contexts, especially in relation to political economy and antiquarianism. See the articles collected in Martin J.S. Rudwick, Lyell and Darwin, Geologists: Studies in the Earth Sciences in the Age of Reform, Aldershot: Ashgate, 2005.

${ }^{69}$ T.S. Kuhn, 'The relations between history and the history of science', Daedalus (1971) 100, pp. 271-304, 302. For related criticisms see Jan Golinski, 'Lost in mediation: the social component of Darwin's science', History of the Human Sciences (1989) 2, pp. 95-103.

${ }^{70}$ H.M. Collins, 'The seven sexes: a study in the sociology of a phenomenon, or the replication of experiments in physics', Sociology (1975) 9, pp. 205-24. For research schools see J.B. Morrell, 'The chemist breeders: the research schools of Liebig and Thomas Thomson', Ambix (1972) 19, pp. 1-46; and Gerald L. Geison, Michael Foster and the Cambridge School of Physiology: The Scientific Enterprise in Late Victorian Society, Princeton, NJ: Princeton University Press, 1978.

${ }^{71}$ Steven Shapin, 'History of science and its sociological reconstructions', History of Science (1982) 20, $157-211$.
} 
The same impulse was evident in work close to Young's areas of original concern. Adrian Desmond's Archetypes and Ancestors: Palaeontology in Victorian London (1982) and The Politics of Evolution: Morphology, Medicine, and Reform in Radical London (1989) combined fiercely fine-grained studies of scientific and medical periodicals with an understanding of political positions, to unmask the ideological underpinnings of disputes about animal bodies and structures. Instead of a 'common context' of debate among 'the intelligentsia', Desmond revealed a society riven by controversies. ${ }^{72}$ Similar work in a variety of fields was carried out at the same time: Crosbie Smith and Norton Wise on thermodynamics and electromagnetism, Evelleen Richards on evolution and development, Simon Schaffer on astronomy. ${ }^{73}$ These outlined precisely the kind of mediations that Young had called for, but for which his methods were not particularly well suited. It would have been hard to imagine Young reading papers about the fossil remains of mammals, the dissection of the frontal cortex, or the reproductive organs of the platypus, but that was where the politics of science was most profoundly expressed.

More generally, Young remained deeply dissatisfied with the direction of academic life in Britain and America. Darwin studies had turned largely inward; from his perspective the new social history of science didn't tackle the big issue of 'man's place in nature' a topic that, despite praise for a few studies by former students, he saw as dominated by theologically inspired waffle about 'science and religion' from lapsed evangelicals. ${ }^{74}$ And for all the references to politics, much of the historical work inspired by sociology of knowledge was narrowly targeted at professional audiences, so that its potential significance was obscured. ${ }^{75}$ As has become clear in the intervening years, the pioneering work by sociologists provided superb resources for dealing with issues inside laboratories, but was less effective in connecting to wider concerns. In retrospect this 'new internalism', evident in some but by no means all of the work, can be seen to reflect a caution induced by the hostile climate faced by academics in the years after 1980. Much of the sociological literature became mired in discussions of epistemology, leading to the fruitless conflicts of the science wars during the late 1990s. The moment in which an author could hope for a heavily researched academic paper in Past and Present to connect with direct political action had passed.

Conversely, when Adrian Desmond and Jim Moore offered a 'defiantly political' portrait of Darwin in their bestselling biography of 1991, Young slammed it in a long review for being too smooth and accessible. ${ }^{76}$ An argument intended to provoke outrage had transmuted into new orthodoxy, a racy narrative that could be advertised to commuters on the

\footnotetext{
${ }^{72}$ For a contemporary survey see James A. Secord, 'Natural history in depth', Social Studies of Science (1985) 15, pp. 181-200.

${ }^{73}$ Crosbie Smith and M. Norton Wise, Energy and Empire: A Biographical Study of Lord Kelvin, Cambridge: Cambridge University Press, 1989; Evelleen Richards, articles collected in Ideology and Evolution in Nineteenth Century Britain: Embryos, Monsters, and Racial and Gendered Others in the Making of Evolutionary Theory and Culture, London: Routledge, 2021; Simon Schaffer, 'Scientific discoveries and the end of natural philosophy', Social Studies of Science (1986) 16, pp. 387-420; and Schaffer, 'Astronomers mark time: discipline and the personal equation', Science in Context (1988) 2, pp. 115-45.

${ }^{74}$ For the praise of former students see Young, op. cit. (42), pp. 162-3.

${ }^{75}$ Steven Shapin, 'Hyperprofessionalism and the crisis of readership in the history of science', Isis (2005) 96, pp. 238-43. On the politics of science studies see the special issue edited by Evelleen Richards and Malcolm Ashmore, The Politics of SSK: Neutrality, Commitment and Beyond, Social Studies of Science (1996) 26(2), pp. 219-468.

${ }^{76}$ Young, op. cit. (61). For reflections on this episode see James Moore, 'Metabiographical reflections on Charles Darwin', in Michael Shortland and Richard Yeo (eds.), Telling Lives in Science: Essays on Scientific Biography, Cambridge: Cambridge University Press, 2008, pp. 267-81. Young's concern about the politics of popular biography were shared by others; see Richards, op. cit. (57), p. 518; Ingemar Bohlin, 'Popularizing Darwin', Science as Culture (1994) 4, pp. 425-39, 419; and Paul White, 'Desmond/Huxley: the hot-blooded historian', Studies in History and Philosophy of the Biological and Biomedical Sciences (2004) 35, pp. 191-8, italics in original.
} 
London Underground. From Young's perspective, rough authenticity had been sacrificed for commercial surface, as had happened in the 1960s as rock music compromised with corporate capitalism - blunting the edge of revolution through repressive sublimation. To quote again from his essay on 'The new nation?' in 1970, 'How much has the music really freed people from oppression and repression, and how much is it a subtle accommodation with them? ${ }^{17}$

It was all too easy. To Young's dismay there was no sense of historiographical debate in the Darwin biography, of what was at stake in the link with Malthus. Young saw more hope for the field through the work of Donna Haraway, which was both deeply engaged and rough around the edges (but accessible only to a tiny fraction of the audience). Whether his response to the biography was justified, the review expressed perfectly why Young had abandoned academia in the first place.

\section{Conclusion}

I met Bob Young on six occasions, the last time in May 2016 at the memorial conference for the much-missed historian of the human sciences John Forrester. So, unlike the others who spoke at a workshop in Cambridge held in Bob's honour following his death in 2019, I never knew him well. For me as for many who entered history of science in the 1970s, Robert M. Young was without question a figure to be reckoned with, but almost entirely through his writings. The first serious book in history of science I owned was his 1973 Festschrift for the sinologist Joseph Needham, Changing Perspectives in the History of Science, co-edited with Mikuláš Teich. I bought this volume in London a couple of years after it came out, and was nearly arrested at Foyles bookshop by a security guard midway on an escalator having failed to understand the bizarre system of paying for books which operated there at the time. Young's long essay, 'The historiographic and ideological contexts of the nineteenth-century debate on man's place in nature', was like nothing I had ever read. Not only did it introduce me to what he later termed the corruption, opportunism, and hypocrisy of certain colleagues and patrons' in Cambridge, ${ }^{78}$ it also opened my eyes to the breath and significance of the subject.

Although I did not know Young at all well, in an important respect I have a unique relationship with him. Ever since arriving in the Department of History and Philosophy of Science in Cambridge in 1992 I have taught courses that are direct descendants of his lectures on Science and Public Debate. For decades I have been hammering home lessons about Malthus, Darwin, natural theology, the 1834 New Poor Law and similar issues to undergraduates in the Natural Sciences Tripos. Every spring I read out the relevant passages from Darwin's notebooks and stress that natural selection was not articulated in isolation in the Galapagos, but on Great Marlborough Street in London, in the midst of a passionate debate about the place of humans in nature. And yet I always suspected that Young thought I was too 'soft', willing to work within a system that he condemned as too corrupt and constraining for the intellectual ventures he wished to undertake.

For what it is worth, my view is that Young never fully appreciated the leverage for change that institutions can bring. Particularly after the advent of Thatcher and Reagan, with the decimation of the labour movement and the systematic destruction of many of the structures on which earlier campaigns had depended, the universities offered one of the few remaining platforms for the expression of alternative views. That is one of the reasons for Young's own partial return to academic life, first through a visiting professorship at Kent (1991-4) and then as professor of psychoanalytic studies at Sheffield

\footnotetext{
${ }^{77}$ Young, op. cit. (7), p. 33.

${ }^{78}$ Young, op. cit. (42), p. x.
} 
(1995-2000). These appointments acknowledged what was by then a substantial body of work in psychology and the human sciences, and his status as a practising psychiatrist. And it is also true, of course, that even places like Cambridge, which remain deeply traditional, have changed during the past half-century, most clearly in attitudes towards diversity. Like Young himself, they have 'moved on'.

For all their grounding in the distant days of the 1960s, Young's writings continue to serve as a disciplinary conscience. The dichotomies he argued against - between science and society, nature and culture, mind and body, internal and external - are still as pervasive as ever, and the forces supporting them have become even more powerful. At the same time, his call to overcome these divisions, and for using the power of history to contribute to breaking them down, are urgent in new ways and for different reasons. Today we see both Malthus and Darwin in wider contexts involving race, gender, immigration and cross-cultural exchange. ${ }^{79}$ The debate about the place of humans in nature is a question not only of belief among the leaders of thought, but of survival. I can thus end with one of Young's favourite quotations from George Eliot: as Dorothea Brooke's uncle says in Middlemarch, 'I went into science a great deal myself at one time; but I saw it would not do. It leads to everything; you can let nothing alone. ${ }^{80}$

\footnotetext{
${ }^{79}$ See, for example, Alison Bashford and Joyce E. Chaplin, The New Worlds of Thomas Robert Malthus: Rereading The Principle of Population, Princeton, NJ: Princeton University Press, 2016; and Marwa Elshakry, 'Global Darwin: Eastern enchantment', Nature (28 October 2009) 461, pp. 1200-1.

${ }^{80}$ Robert M. Young, 'Darwin's metaphor: does nature select?', The Monist (1971) 55, pp. 442-503, 503.
} 